\title{
PEMODELAN 3D ANALYSIS RISIKO BENCANA WISATA LERENG GUNUNG MERAPI DI KECAMATAN CANGKRINGAN DAN PAKEM
}

\author{
Rahma Nur Hasanah $^{1}$, Riko Arrasyid ${ }^{2 *}$, Ridho Dwi Sumanto ${ }^{3}$, Yoga Munawar Khahfi ${ }^{4}$ \\ ${ }^{1,3,4}$ Program Studi Sains Informasi Geografi, FPIPS, Universitas Pendidikan Indonesia \\ ${ }^{2}$ Program Studi Pendidikan Pariwisata, FPIPS, Universitas Pendidikan Indonesia \\ *rikoarrasyid@upi.edu
}

\begin{tabular}{|c|c|}
\hline \multicolumn{2}{|c|}{ INFO ARTIKEL } \\
\hline \multicolumn{2}{|c|}{ Riwayat Artikel: } \\
\hline Dikirim & $07-04-2020$ \\
\hline Disetujui & $25-05-2020$ \\
\hline Diterbitkan & $19-06-2020$ \\
\hline
\end{tabular}

\section{Kata kunci:}

Pariwisata, Risiko, Bencana, Pemodelan 3D Analysis

\section{PENDAHULUAN}

Sektor pariwisata merupakan sektor unggulan yang menjadi salah satu faktor penting dalam pembangunan wilayah dan peningkatan kesejahteraan masyarakat di suatu negara yang telah mengalami ekspansi dan diversifikasi berkelanjutan serta menjadi salah satu sektor yang mengalami pertumbuhan terbesar di dunia (Kementrian Pariwisata, 2015).

\section{ABSTRAK}

Abstract: As a country located in an area where three active plates meet, Indonesia has a high level of disaster risk, including volcanic eruptions. Indonesia has active volcanoes more than $30 \%$ of all active volcanoes in the world. One of the most frequent volcanoes that erupts is Mount Merapi, since 1900 up to now there have been recorded 24 eruptions. From our concern about the threat of disaster, we are interested in developing $3 D$ Analysis modeling for tourist areas in Cangkringan and Pakem Districts. The combination of GIS technology with navigation systems can be used as a tool to analyze the state of tourist areas against disasters from Mount Merapi. From the 3D Analysis modeling that has been made, Bukit Klangon which is opened to the public is the highest position compared to other tourist sites and has the closest distance to the caldera. However, in spatial calculations, this tourism location is not one of the tourist areas with the highest hazard vulnerabilities.

\begin{abstract}
Abstrak: Sebagai Negara yang terletak di daerah pertemuan 3 lempeng aktif, Indonesia memiliki tingkat risiko bencana yang tinggi, diantaraya adalah erupsi gunung api. Indonesia mempunyai gunung api aktif lebih dari $30 \%$ dari keseluruhan gunung aktif di dunia. Salah satu gunung api yang paling sering meletus adalah Gunung Merapi, sejak tahun 1900 sampai saat ini tercatat sudah 24 kali erupsi. Dari kekhawatiran kami terhadap ancaman bencana tersebut, kami tertarik untuk mengembangkan pemodelan 3D Analysis untuk daerah wisata di Kecamatan Cangkringan dan Pakem. Kombinasi teknologi SIG dengan sistem navigasi dapat digunakan sebagai salah satu alat untuk menganalisis keadaan daerah wisata terhadap bencana dari Gunung Merapi. Dari pemodelan 3D Analysis yang telah dibuat, Bukit Klangon yang dibuka untuk umum menjadi posisi paling tinggi dibanding lokasi wisata lain dan memiliki jarak terdekat dengan kaldera. Namun secara perhitungan spasial, lokasi wisata ini bukan termasuk kawasan wisata dengan kerentanan bahaya paling tinggi.
\end{abstract}

Perencanaan pariwisata tidak dimaksudkan untuk merusak lingkungan hidup tetapi harus direncanakan dan dilaksanakan ke arah tata lingkungan yang mendukung mitigasi bencana. Bencana adalah rangkaian peristiwa yang mengancam dan mengganggu kehidupan dan penghidupan masyarakat yang disebabkan oleh faktor alam dan faktor non alam maupun faktor manusia sehingga mengakibatkan timbulnya korban jiwa manusia, kerusakan 
lingkungan, kerugian harta benda, dan dampak psikologis (UU No. 24 Tahun 2007).

Adanya gunung api memberikan nilai tersendiri yang sesungguhnya menawarkan peluang kegiatan pariwisata yang sangat potensial bagi masyarakat sekitar, karena alamnya yang memiliki keunikan dan berbeda dari daerah lainnya. Namun pariwisata yang dikelola oleh masyarakat berpotensi terkena dampak dari bencana gunung api tersebut, terutama jika lokasi berada di lereng gunung serta kesadaran dan kesiapsiagaan dari pengelola yang masih kurang.

Sebagai Negara yang terletak di daerah pertemuan 3 lempeng aktif, Indonesia memiliki tingkat risiko bencana yang tinggi. Indonesia mempunyai gunung api aktif lebih dari $30 \%$ dari keseluruhan gunung aktif di dunia. Tiga besar bencana yang paling mematikan (8000165.708 jiwa) yaitu tsunami, gempa bumi, dan letusan gunungapi menurut data historis bencana (EM-DAT: OFDA/CRED International Disaster Database).

Salah satu gunung api yang paling sering meletus adalah Gunung Merapi, sejak sekitar tahun 1900 sampai saat ini selalu aktif dengan 24 kali erupsi periode diam atau istirahat pendek (rata-rata tidak lebih dari 3,5 tahun). Letusan Gunung Merapi tahun 2010 adalah letusan yang terbesar dalam 100 tahun terakhir yang mengeluarkan banyak sedimen yang menjadi lahar dingin pada musim penghujan. Lahar dingin terjadi sebanyak 280 kali selama bulan Oktober tahun 2010 hingga Februari tahun 2011 (Surono et al., 2012).

Gunung Merapi memiliki tipe letusan khusus yaitu tipe merapi dengan ciri khas awan panas atau guguran yang berbeda dengan tipe lainnya (Voight, et al, 2000). Arah gerakan awan panas tipe merapi memusat ke satu arah, sehingga daerah bahaya awan panas bersifat sektoral untuk lereng yang dituju. Ciri khas Gunung Merapi adalah kubah lava, aktivitas merapi tahun 2006 menghasilkan kubah yang tumbuh di dekat pelataran Gendol, sehingga lereng aktif pun berubah menjadi selatantenggara dan sungai yang paling rawan adalah kali Gendol.

Lahar dingin dan awan panas tergolong bahaya gunung api yang paling mematikan. Keduanya telah mengakibatkan jatuhnya banyak korban jiwa, kerusakan infrastruktur, kerugian ekonomi, dan kekacauan yang mengganggu kehidupan (Smith and Petley, 2009; Witham, 2005). Lahar dingin adalah salah satu bahaya gunung api yang dapat terjadi diluar periode erupsi dan terjadi ketika bercampurnya material vulkanik dengan air hujan. Lahar dingin menjadi berbahaya pada saat besarnya volume material yang terbawa air mengalir di sungai yang berhulu di gunung api dan menerjang permukiman dan infrastruktur di wilayah hilir (W ood and Soulard, 2009).

Bahaya gunung api yang terjadi diluar periode erupsi akan mengancam masyarakat yang tinggal di lereng gunung, karena waktu terjadinya yang tidak dapat diprediksikan. Karena itu tentu membutuhkan penanganan khusus dalam pengembangan pariwisatanya dengan menerapkan konsep yang berbasiskan mitigasi bencana. Kawasan gunung api di Indonesia merupakan daerah pertanian yang subur dan selalu padat penduduk sejak zaman dahulu, walaupun memiliki ancaman bencana letusan.

Penduduk yang menghuni Kawasan Rawan Bencana III (daerah-daerah yang secara historis terpengaruh aliran piroklastik) dan Kawasan Rawan Bencana II (daerah yang masih dapat di capai oleh jatuhan bahan- bahan lepas) pada tahun 1976 sebanyak 40.800 jiwa dan 72.600 jiwa, sedang pada tahun 1995, menjadi 79.100 jiwa dan 114.800 jiwa (Alz war, M., dkk, 1988 ; Thour et, J.C., et al, 2000). Kenaikan jumlah penduduk di kedua wilayah tersebut, pertahunnya sekitar 3,91\% dan 2,42\%. Artinya pertumbuhan di KRB III (daerah yang di rekomendasikan kosong dari permukiman) lebih besar dari pada di KRB II (daerah bawahnya). Penduduk semakin mendekati sumber bahaya dalam jumlah yang semakin banyak. Sedangkan pada kecamatan Cangkringan dan Pakem berada pada kawasan rawan bencana II dan III.

Seiring dengan perkembangan teknologi informasi yang pesat, SIG (Sistem Informasi Geografi), menjadi salah satu sarana alternatif penting untuk melakukan pemantauan gunung berapi. Dimana Sistem Informasi Geografi adalah kombinasi perangkat keras dan perangkat lunak komputer yang memungkinkan untuk mengelola (manage), menganalisa dan memetakan informasi spasial berikut data atributnya.

SIG juga menganalisis lokasi spasial dan mengatur informasi ke dalam visualisasi 
menggunakan peta dan tampilan 3D. Menurut Xu (2003) ; Cao \& Lu (2012), informasi posisi dapat digunakan dalam SIG untuk menganalisis dunia nyata atau membuat model. Dengan memanfaatkan Sistem Informasi Geografi (SIG) diharapkan mampu untuk menganalisis aspek suatu daerah sehingga potensi-potensi wisata yang ada dapat dikembangkan menjadi obyek dan daya tarik wisata secara optimal yang dapat menarik kunjungan wisatawan. Maka pembangunan pariwisata harus didasarkan pada kriteria keberlanjutan yang artinya bahwa pembangunan dapat didukung secara ekologis dalam jangka panjang sekaligus layak secara ekonomi adil secara etika dan sosial terhadap masyarakat (Piagam Pariwisata Berkelanjutan, 1995).

Seiring perkembangan teknologi, kebutuhan akan visualisasi data yang berkembang membutuhkan tampilan yang lebih tampak nyata. Tampilan 3 dimensi dapat memberikan sudut pandang yang berbeda dari suatu objek, sehingga memungkinkan hasil analisis yang lebih baik dibandingkan tampilan 2 dimensi yang hanya memberikan satu sudut pandang berbagai objek di permukaan bumi khususnya pemodela gunungapi yang memiliki banyak sector pariwisata sehingga dapat digunakan untuk mengelola keadaan darurat.

\section{TUJUAN PENELITIAN}

Tujuan dari penelitian ini adalah sebagai berikut.

1. Mengetahui sebaran daerah wisata di Kecamatan Cangkringan dan Kecamatan Pakem.

2. Mengetahui sebaran DAM/Bendungan dan jembatan yang terdampak jika terjadi erupsi Gunung Merapi.

3. Mengetahi dan menganalisis kelas resiko bencana Gunung Merapi terhadap daerah wisata di Kecamatan Cangkringan dan Kecamatan Pakem.

4. Sebagai bahan acuan baru untuk menerapkan kebijakan mitigasi bencana di daerah kajian.

5. Sebagai bentuk kontribusi penulis dalam upaya mitigasi bencana Gunung Merapi.

\section{METODE PENELITIAN}

\section{Lokasi Penelitian}

Lokasi penelitian ini berada di Kecamatan Cangkringan dan Pakem, Kabupaten Sleman, Provinsi Daerah Istimewa Yogyakarta.

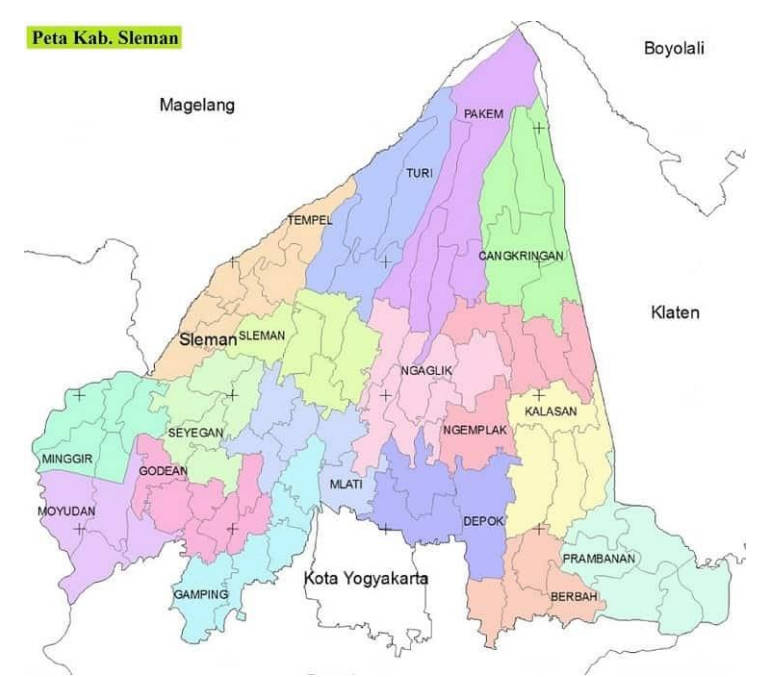

Gambar 1. Peta Kabupaten Sleman

Kecamatan Cangkringan dan Kecamatan Pakem merupakan dua kecamatan paling utara di Kabupaten Sleman, bahkan paling utara juga di Provinsi Yogyakarta. Kecamatan Pakem merupakan salah satu kecamatan di selatan Gunung Merapi yang berada di Kabupaten Sleman, Provinsi Daerah Istimewa Yogyakarta. Bentangan wilayahnya berupa perbukitan, tanah yang berombak, serta pegunungan. Ibukota kecamatannya berada pada ketinggian 600 mdpl dengan suhu kisaran $18^{\circ} \mathrm{C}-32^{\circ} \mathrm{C}$. Jarak puncak Gunung Merapi ke Kantor Kecamatan Pakem adalah 14.29 km. Jarak Ibukota Kecamatan ke Pusat Pemerintahan (Ibukota) Kabupaten Sleman adalah $14 \mathrm{Km}$. Lokasi ibu kota kecamatan Pakem berada di 77.66708' LS dan 110.42011' BT. Kecamatan Pakem mempunyai luas wilayah 4.384,04 Ha. Jumlah penduduk di Kecamatan Pakem sebanyak 36.804 jiwa (BPS, 2018). Letaknya yang berada di lereng Gunung Merapi membuat banyak objek wisata yang menyumbang $40 \%$ dari Produk Domestik Regional Bruto Kecamatan Pakem.

Sedangkan Kecamatan Cangkringan merupakan kecamatan di Kabupaten Sleman yang berada di bagian tenggara Gunung Merapi. Dari Kantor Kecamatan Cangkringan ke puncak Gunug Merapi berjarak 13.09 km. 
Ibukota kecamatannya berada pada ketinggian 400 mdpl dengan suhu kisaran $23^{\circ} \mathrm{C}-33^{\circ} \mathrm{C}$. Jarak Ibukota Kecamatan ke Pusat Pemerintahan (Ibukota) Kabupaten Sleman adalah $25 \mathrm{Km}$. Lokasi ibu kota kecamatan Cangkringan berada di 7.66406' LS dan 110.46143' BT. Kecamatan Cangkringan mempunyai luas wilayah $4.799 \mathrm{Ha}$. Bentangan wilayahnya perbukitan dan pegunungan, semakin ke utara semakin terjal dengan kemiringan $30-50 \%$. Jumlah penduduk di Kecamatan Cangkringan sebanyak 29.456 jiwa (BPS, 2018). Kedua kecamatan ini memiliki banyak daerah wisata yang memiliki ancaman atau potensi cukup serius jika terjadi bencana erupsi karena berada pada daerah lereng Gunung Merapi, yang kemudian membuat kami tertarik untuk melakukan penelitian ini.

Ada 26 lokasi wisata di lereng Gunung Merapi yang di tandai, ada wisata alam yang dibuka untuk umum dan yang dibuka khusus serta wisata yang berbentuk museum atau di dalam ruangan. Lokasi wisata tersebut didapatkan dari objek wisata yang sudah terfaftar di Google Maps.

\section{Alat dan Bahan}

Alat yang digunakan dalam penelitian ini sebagai berikut.

1. 3 buah laptop

2. 3 buah handphone

3. Software ArcGIS 10.4

4. Software ArcScene

5. Software Ms. Word

6. Software Google Earth

7. Google Maps

Sedangkan bahan yang digunakan dalam penelitian ini sebagai berikut.

1. Data DEM Provinsi Yogyakarta

2. Data Citra DEMNAS Provinsi Yogyakarta

3. Data Koordinat (Plot) Lokasi wisata di lereng Kecamatan Pakem dan Cangkringan

4. Data Koordinat (Plot) Bendungan di Provinsi DIY

5. Data Koordinat (Plot) Jembatan di Provinsi DIY

6. Data Koordinat (Plot) DAM di Provinsi DIY

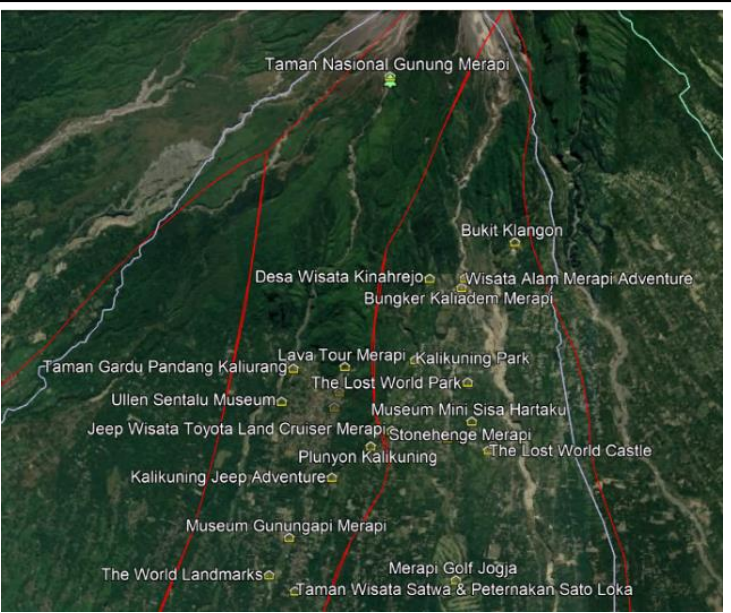

Gambar 2. Sebaran Lokasi Wisata

\section{Metode}

Teknik analisis spasial yang digunakan meliputi analisis buffer daerah, 3D analysis, dan overlay. Analisis buffer daerah ini dimaksudkan untuk mengetahui cakupan atau daerah yang kemungkinan terdampak bahaya yang disebabkan oleh Gunung Merapi, mulai dari tempat wisata, DAM/ Bendungan, maupun jembatan yang kemungkinan terdampak. Buffer sendiri dipetakan dengan mempertimbangkan jarak. Kemudian, 3D Analysis ini dilakukan untuk mempermudah dalam menginterpretasi dan menganalisis kajian. Menggunakan tampilan model 3 dimensi (3D) dilakukan lebih berguna karena memberikan representasi lain (warna dan bentuk) dan kemiripan yang lebih baik seperti kenampakan dunia nyata (Skarkawi et al., 2008 ; Cao \& Lu, 2012).

$3 D$ Analysis digunakan untuk menganalisis morfologi lereng selatan Gunung Merapi dan mengidentifikasi serta mengukur kedalaman/ketinggian profil atau topografi dari lembah dan bukit. Selanjutnya melakukan overlay, dimana hasil dari buffer daerah dan 3D Analysis di overlay menampalkan suatu peta digital pada peta digital yang lain beserta atribut-atributnya dan menghasilkan peta gabungan keduanya yang memiliki informasi atribut dari kedua peta tersebut. Overlay sendiri merupakan proses penyatuan data dari lapisan layer yang berbeda. Secara sederhana overlay disebut sebagai operasi visual yang membutuhkan lebih dari satu layer untuk digabungkan secara fisik.

\section{Diagram Alir}




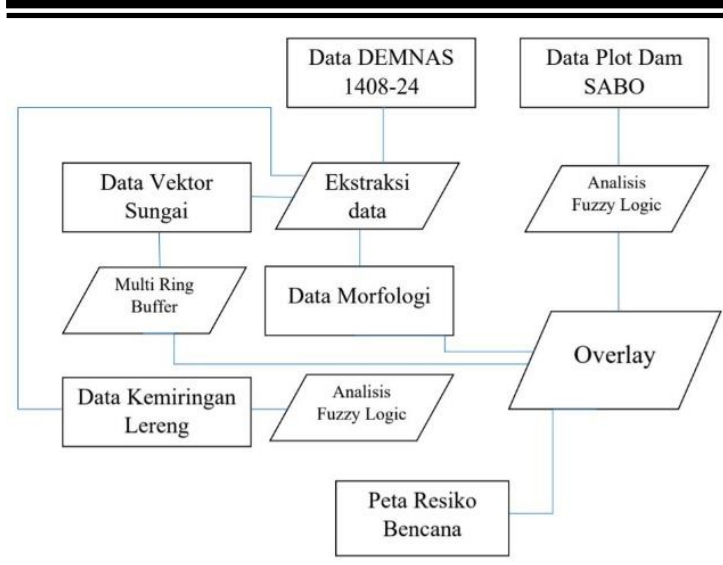

Gambar 3. Diagram Alir Pengolahan

Dari diagram alir yang telah dibuat, tahapan pengerjaan penelitian dimulai dari mengumpulkan data DEMNAS 1408-24 dan Data Plot DAM SABO. Data DEMNAS kemudian di ekstraksi menjadi tiga bagian yaitu Data vector sungai, Data Morfologi dan Data Kemiringan Lereng. Data vektor sungai kemudian diolah menjadi Multi Ring Buffer lalu untuk data Kemiringan lereng kemudian dilanjutkan dengan Analisis Fuzzy Logic. Setelah itu, data morfologi, hasil Multi Ring Buffer dan hasil dari analisis fuzzy logic di overlay dan akhirnya dihasilkan Peta Resiko Bencana. Selain itu ada juga rumus dari pengolahan data yaitu:

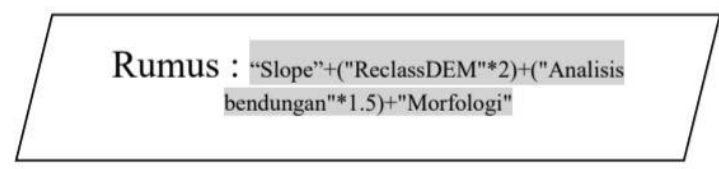

Gambar 4. Rumus Pengolahan Data

Pada bagian ini penulis menjelaskan proses penelitian di lakukan. Materi pokok pada bagian ini terdiri dari rancangan penelitian, penentuan populasi dan sampel, teknik pengumpulan data, teknik pengembangan instrument, serta teknik analisa data. Untuk penelitian yang menggunakan alat, bahan, program atau software. Maka perlu dijelaskan mengenai spesifikasi alat yang digunakan. sedangkan spesifikasi bahan menggambarkan macam bahan yang digunakan.

Untuk penelitian kualitatif seperti penelitian tindakan kelas, etnografi, fenomenologi, studi kasus, dan lain-lain, perlu ditambahkan kehadiran peneliti, subyek penelitian, informan yang ikut membantu beserta cara-cara menggali data-data penelitian, lokasi dan lama penelitian serta uraian mengenai pengecekan keabsahan hasil penelitian.

\section{HASIL DAN PEMBAHASAN}

Analisis Alur Pengolahan Data

Untuk melakukan analisis kerentanan lokasi pariwisata di lereng Gunung Merapi, maka diperlukan rancangan awal besaran dampak atau gambaran di masa lampau mengenai alur dari material letusan Gunung Merapi yang meluluh lantahkan kedua kecamatan tersebut. Bencana alam primer, menjadi penyebab utama kerusakan total dari seluruh pemukiman dan korban jiwa yang berada di kecamatan cangkringan dan kecamatan pakem. Letusan Gunung merapi meluncur sejauh $9 \mathrm{~km}$ dari pusat kawah. Selain itu, terdapat pula bencana erupsi sekunder, berupa sisa-sisa material vulkanik yang berjumlah jutaan ton meter kubik. Materialmaterial tersebut mengalir melalui dua sungai utama yang berhulu ke merapi, yakni kali gendol dan kali opak. Diantara dua kali tersebut, kali opak adalah kali dengan ketinggian dasar sungai yang paling rendah. Sehingga lebih memungkinkan untuk memuat aliran material jauh lebih besar dari sungai lainnya. aliran sisa material vulkanik yang bergerak dalam jumlah yang sangat besar, memiliki daya rusak yang cukup tinggi apabila tidak di persiapkan dengan baik. Dua sungai utama ini mampu memberikan ancaman pada 12 aliran sungai yang mengarah langsung ke kota Yogyakarta. Bahkan beberapa diantaranya, ada yang mengarah langsung ke salah satu objek cagar budaya terkenal, yakni candi prambanan, yang bisa memutus jalur antar kota.

Dari kedua bencana tersebut, memiliki dampak yang cukup besar terhadap objek-objek yang secara langsung berhadapan dengannya. Oleh karena itu, objek infrastruktur yang rusak dengan tingkatan rusak tertentu, seharusnya mampu memberikan gambaran lebih jelas dari aliran material vulkanik yang terjadi di masa lampau tersebut. Dengan melakukan pemetaan lokasi dari objek-objek fisik yang terdampak dari fenomena tersebut, dapat diketahui polapola aliran atau bencana yang terjadi secara spesifik. Hal ini, akan memberikan rancangan lebih detail dari kedua bencana ini yang 
bergerak dan menghancurkan objek fisik dengan pola tertentu.

\section{Pemetaan Sungai}

Aliran sungai yang berhulu di gunung merapi, memiliki karakteristik sebagai sungai yang mengalirkan material vulkanik berbentuk awan panas, lahar dingin, atau bahkan guguran lava yang masih belum mendingin. Sungai akan menjadi area yang membantu material piroklastik untuk bergerak lebih jauh dari pusat erupsi dan menjadi tempat hilir dari material vulkanik dari area kaki gunung yang lebih datar.

Terdapat 2 sungai utama yang menjadi fokus itama dalam penelitian ini, yakni kali gendol dan kali opak. Dari dua sungai tersebut, mampu mengalirkan jutaaan ton metric material vulkanik dan mengancam sekitar 12 aliran sungai yang menembus kota Yogyakarta. Dari kedua sungai utama yang berhulu di gunung merapi, kali gendol merupakan sungai terendah yang berpotensi besar menampung aliran material vulkanik jauh lebih banyak.

\section{Pemetaan Objek Fisik}

Bersumber dari inventarisasi BPBD Yogyakarta, terdapat berbagai infrastruktur yang mengalami kerusakan dengan berbagai tingkatan. Diantaranya adalah kerusakan yang terjadi pada dam atau bendungan sabo yang berfungsi secara langsung menahan material vulkanik. Selain itu adapula dam yang berfungsi sekaligus menjadi jembatan penghubung antar desa yang sering digunakan warga dalam melakukan aktifitas berdagang. Sekitar ratusan unit bendungan sabo di daerah kawasan bencana primer, mengalami kerusakan berat. Kawasan bencana primer ini merupakan wilayah yang langsung berhadapan dengan erupsi gunung merapi, sehingga sebagian besar kerusakan disebabkan oleh dampak dari erupsi secara langsung.

\section{Buffering Sungai}

Buffering sungai ini dilakukan sebagai bentuk dari pemodelan untuk mengklasifikasi seberapa dekat atau besaran potensi luapan banjir lahar dingin yang mengalir di sungai daerah wisata lereng Gunung Merapi. Menggunakan teknik buffer ini kita dapat mengkelaskan wilayah mulai dari wilayah berpotensi tinggi, sedang hingga rendah.

\section{Buffering Point DAM atau Jembatan}

Tidak jauh berbeda dengan buffer sungai, buffer point atau jembatan dimaksudkan untuk mengklasifikasi daerah wisata di lereng terhadap potensi banjir lahar dingin yang ditimbulkan dari Gunung Merapi sebagai gejala alam. Diasumsikan bahwa ketika DAM atau jembatan sudah tidak bisa berfungsi, maka akan memberikan dampak bagi daerah sekitar nya atau wilayah yang dilewati aliran sungai tersebut. Karena peristiwa jebolnya bendungan, dapat berakibat mempercepat gerak aliran lahar dingin atau awan panas ke tempat yang lebih rendah. Tentu dengan kecepatan tinggi tersebut, bisa memberikan efek hantaman yang lebih besar lagi pada wilayah yang akan dilewatinya.

\section{Gambaran Alur Awan Panas}

Gambaran alur awan panas yakni pemodelan spasial yang menggunakan arah dari beberapa sungai atau lereng yang kemudian dapat digunakan sebagai rujukan mitigasi jika terjadi erupsi dari Gunung Merapi. Parameter tersebut terdiri dari faktor pendukung dari luncuran awan panas berupa kemiringan lereng dan adapun faktor morfologi yang bisa memberikan pengaruh pendukung atau bisa menjadi penghambat.

\section{Elevation Model}

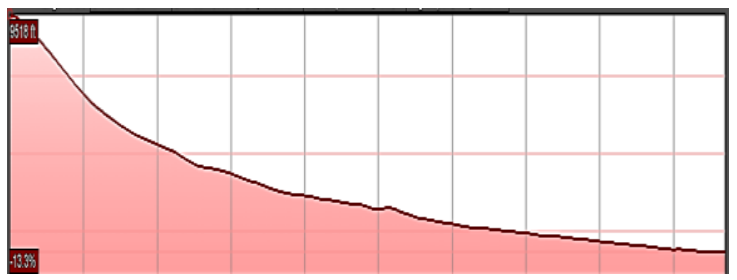

Gambar 5. Elevation Model

Gambaran tersebut menunjukan lereng dari puncak gunung ke lokasi wisata paling selatan yaitu Argo Wisata Bhumi Merapi. Dengan ketinggian Gunung Merapi yaitu 2930 
meter dan ketinggian Argo Wisata Bhumi Merapi 570.89 meter. Mulai landai pada ketinggian 1219,2 meter hingga ke lokasi wisata paling selatan di plot.

\section{PEMBAHASAN}

\section{Analisis Potensi Rawan Bencana}

Analisis potensi kerawanan dilakukan dengan analisis gabungan antara overlay data dari hasil perumusan kerawanan bahaya erupsi dan banjir lahar dengan pemodelan 3 dimensi dari data plot kawasan wisata serta DEMNAS.

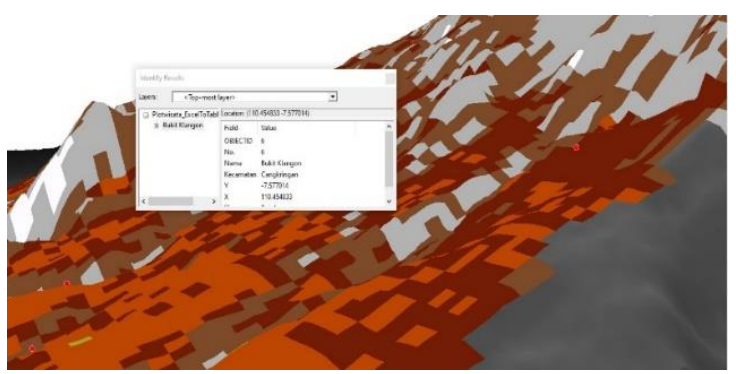

Gambar 6. Plot Lokasi Bukit Klangon

Berdasarkan hasil pengamatan pada overlay data 3 dimensi dengan plot lokasi wisata, didapatkan informasi berupa lokasi dan ketinggian serta gambaran relief di sekitar lokasi wisata. Hal ini berkaitan juga dengan pengamatan pada titik lokasi wisata Bukit Klangon yang dibuka untuk umum menjadi posisi paling tinggi dibanding lokasi wisata lain dan memiliki jarak terdekat dengan kaldera. Hanya saja ternyata secara perhitungan spasial, lokasi wisata ini bukan termasuk kawasan wisata dengan kerentanan bahaya paling tinggi. Hal ini bisa saja terjadi karena ada faktor penghambat untuk bahaya erupsi yang menjadikan kawasan ini sedikit lebih tidak berbahaya walaupun memiliki jarak terdekat dengan kawah vulkanik.

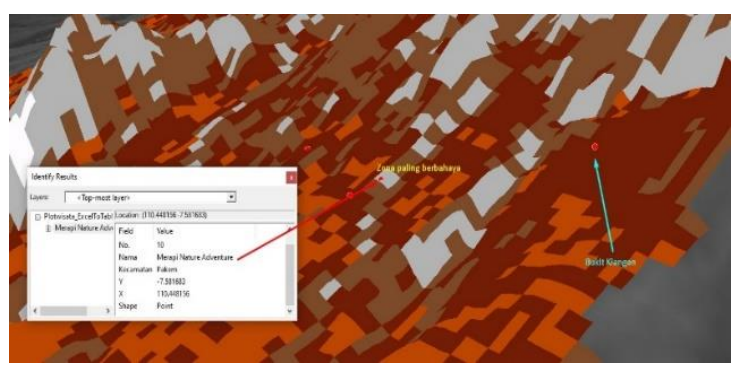

Gambar 7. Plot Lokasi Merapi Nature Adventure
Lokasi dari wisata Merapi Nature Adventure memiliki potensi paling tinggi berdasarkan perhitungan simulasi alur material letusan. Hal ini bisa disebabkan dari perhitungan faktor penghambat yang mungkin jauh lebih sedikit dibandingkan dengan faktor penghambat di objek wisata Bukit Klangon. Walaupun dari segi jarak, lokasi wisata ini sedikit lebih jauh jaraknya dengan kawah vulkanik. Berdasarkan skenario alur material letusan, lokasi ini yang akan memiliki dampak terbesar dibanding kawasan wisata lainnya. Selain itu adapun salah satu lokasi objek wisata yang memiliki posisi terjauh dari kawah vulkanik.

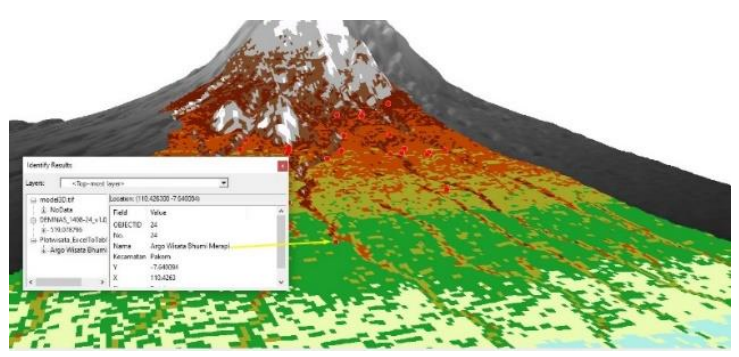

Gambar 8. Plot Lokasi Argo Wisata Bhumi Merapi

Lokasi wisata ini dapat diasumsikan sebagai objek wisata yang memiliki potensi terkena dampak yang paling kecil di zona kawasan rentan bahaya erupsi. Objek wisata tersebut memiliki cukup banyak faktor pendukung yang mampu menjadikan lokasi tersebut menjadi lokasi dengan dampak erupsi paling kecil. Jika dilihat dari bentuk lahannya, memiliki karkateristik yang lebih landai dan jarak yang jauh dari pusat erupsi.

\section{Analisis Lokasi}

Terdapat 26 lokasi wisata yang ada di lereng Gunung Merapi Kecamatan Pakem dan Cangkringan, jarak yang terdekat dari Gunung Merapi yaitu Taman Nasional Gunung Merapi sekitar $1.92 \mathrm{~km}$ dan yang terjauh sekitar 11.18 km yaitu Argo Wisata Bhumi Merapi. Setelah wilayahnya diberi kelas maka dapat diketahui bahwa ternyata paling banyak lokasi wisata di lereng tersebut berada di kelas risiko bencana 5 . 
Tabel 1. Lokasi Wisata di Lereng Gunung Merapi

\begin{tabular}{|c|c|c|c|c|}
\hline No & Nama & Kecamatan & $\begin{array}{c}\text { Jarak dari Puncak } \\
(\mathbf{k m})\end{array}$ & $\begin{array}{l}\text { Kelas } \\
\text { Risiko }\end{array}$ \\
\hline 1. & Taman Nasional Gunung Merapi & Pakem & 1.92 & 9 \\
\hline 2. & Lava Tour Merapi & Pakem & 5.99 & 5 \\
\hline 3. & Lava Merapi and Batu Alien & Cangkringan & 6.88 & 5 \\
\hline 4. & $\begin{array}{l}\text { Jeep Wisara Toyota Land Cruiser } \\
\text { Merapi }\end{array}$ & Cangkringan & 6.78 & 5 \\
\hline 5. & Bungker Kaliadem Merapi & Pakem & 4.65 & 6 \\
\hline 6. & Bukit Klangon & Cangkringan & 4.12 & 7 \\
\hline 7. & The Lost World Castle & Cangkringan & 7.05 & 5 \\
\hline 8. & Desa Wisata Kinahrejo & Cangkringan & 4.52 & 6 \\
\hline 9. & Kalikuning Park & Cangkringan & 5.71 & 5 \\
\hline 10. & Merapi Nature Adventure & Pakem & 4.51 & 6 \\
\hline 11. & The Lost World Park & Cangkringan & 7.05 & 5 \\
\hline 12. & Kalikuning Jeep Adventure & Pakem & 7.61 & 5 \\
\hline 13. & Stonehenge Merapi & Cangkringan & 6.80 & 5 \\
\hline 14. & Desa Wisata Petung & Cangkringan & 6.85 & 5 \\
\hline 15. & Museum Mini Sisa Hartaku & Cangkringan & 6.61 & 5 \\
\hline 16. & Desa Wisata Kaliurang Timur & Pakem & 6.37 & 5 \\
\hline 17. & Taman Gardu Pandang Kaliurang & Pakem & 6.26 & 4 \\
\hline 18. & Hobbit House Merapi & Cangkringan & 6.98 & 5 \\
\hline 19. & Museum Gunung Merapi & Pakem & 8.62 & 3 \\
\hline 20. & Plunyon Kalikuning & Cangkringan & 7.05 & 5 \\
\hline 21. & Merapi Golf Jogja & Cangkringan & 8.93 & 3 \\
\hline 22. & The World Landmarks & Pakem & 9.25 & 3 \\
\hline 23. & $\begin{array}{l}\text { Taman Wisata Satwa \& Peternakan } \\
\text { Sato Loka }\end{array}$ & Pakem & 9.37 & 3 \\
\hline 24. & Argo Wisata Bhumi Merapi & Pakem & 11.18 & 2 \\
\hline 25. & Ullen Sentalu Museum & Pakem & 6.77 & 4 \\
\hline 26. & $\begin{array}{l}\text { Museum Gempa Prof. Dr. Sarwidi } \\
\text { (MGS 02) }\end{array}$ & Pakem & 6.60 & 5 \\
\hline
\end{tabular}

Arah panah tersebut merupakan gambaran prediksi arah awan panas yang melewati Kecamatan Pakem dan Cangkringan, semakin banyak jumlah simbolnya menandakan kemungkinan besar awan panas berpola kearah itu. Sedangkan dilihat dari kelas risiko bencana, wilayah yang berwarna ungu tua itu memiliki faktor pendukung dari konsentrasi awan panas yang sudah tinggi, sehingga memiliki risiko yang paling tinggi.

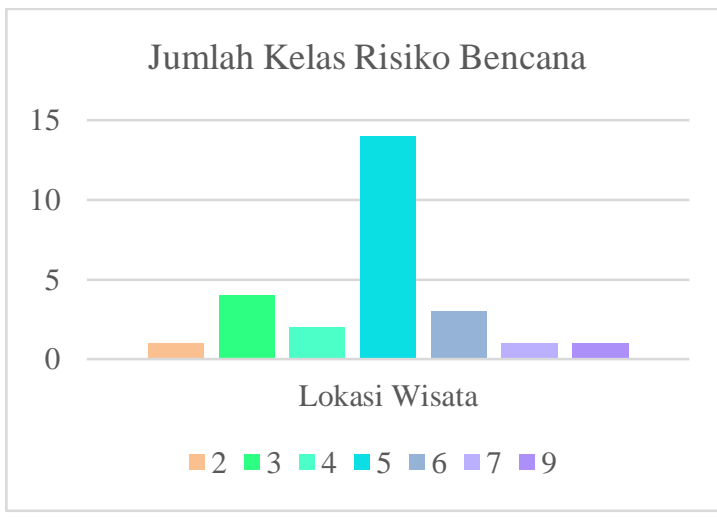

Gambar 9. Kelas Resiko Bencana Lokasi Wisata 


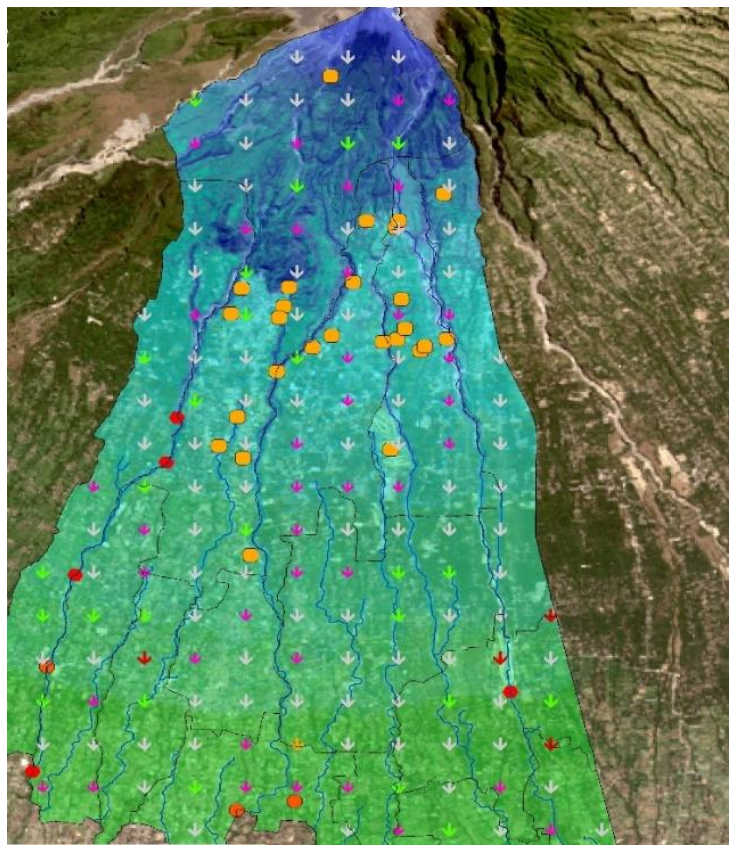

Gambar 10. Pemodelan Risiko Bencana

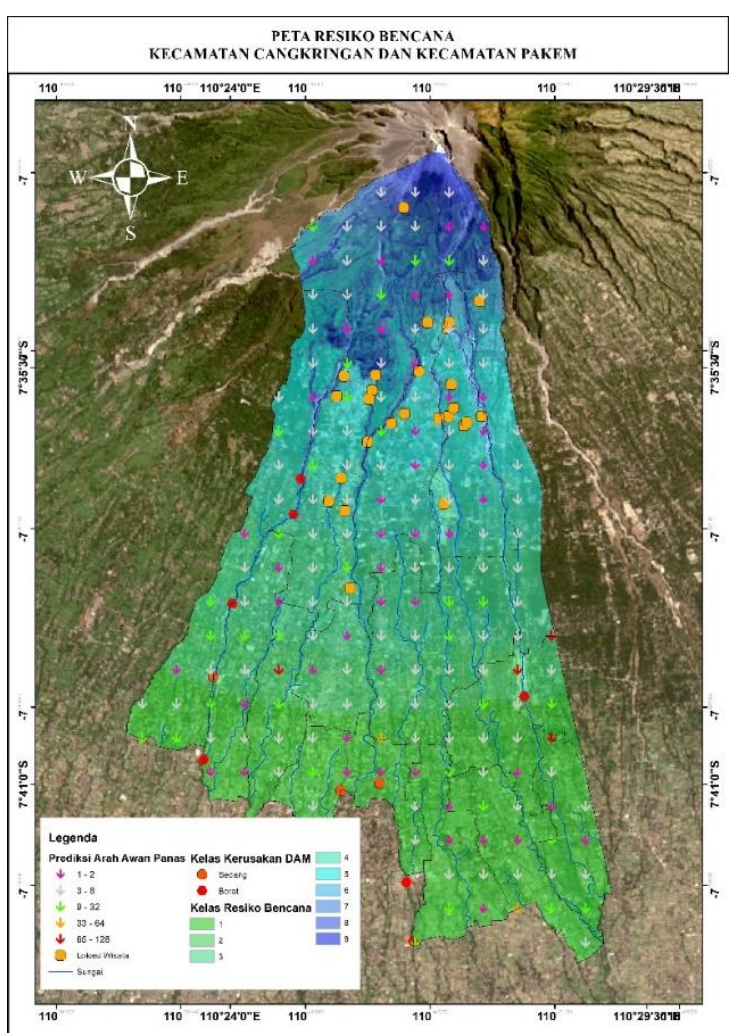

Gambar 11. Hasil Layout Peta

Selain dari pemodelan 3D Analisis dibuat juga peta visualisasi alur dari awan panas atau lahar dingin. Dimana dalam peta tersebut ditunjukan arah aliran yang begitu kompleks mengacu pada kemiringan dan juga daerah yang dilalui. Dalam visualisasi yang ditampilkan terlihat juga bahwa kemungkinan dari tersebarnya aliran sangat luas dan rapat yang artinya dalam proses mitigasi dari bencanya erupsi harus lebih ditingkatkan.

\section{SIMPULAN}

Penyusunan Model 3D Analysis membuat kemiringan lokasi wisata yang berada di lereng tersebut terlihat dengan jelas. Lokasi yang berada di cekungan atau perbukitan pun terlihat, serta jalur sungai yang memiliki hulu dari Gunung Merapi Jelas terlihat besarannya dan dapat dibandingkan kedalamannya antar sungai. Dengan tampilan 3D tersebut memudahkan penyusun untuk menganalisis dan memudahkan pembaca untuk mengerti karena gambarannya lebih terlihat asli. Dari 26 lokasi wisata di lereng Gunung merapi 53.85\% berada di kelas risiko bencana 5. Wilayah Kecamatan Pakem dan Cangkringan dilewati oleh 3 Sungai yang memiliki hulu di Gunung Merapi, yang terbesar adalah Kali Gendol yang dapat berpotensi membawa bahan-bahan hasil letusan lebih banyak seperti awan panas atau lahar dingin ke wilayah dengan ketinggian yang lebih rendah. Adanya bukit-bukit disekeliling objek wisata dapat meningkatkan perlingungan saat Gunung Merapi meletus. Adanya pembangunan berkelanjutan dengan memperahatikan faktor bencana yang akan terjadi dan dapat merusak objek tersebut perlu diperhatikan, karena sektor pariwisata dapat berdampak langsung terhadap ekonomi masyarakat di wilayah tersebut.Hasil dan pembahasan ditulis dalam satu judul besar (UPPERCASE) dan Bold, dan jika terdapat sub judul maka disesuaikan, dengan sub judul di tulis secara Capital Each Word dan Bold.

\section{DAFTAR PUSTAKA}

BNPB Provinsi DIY. (2013). Rencana Aksi Reha (Saputra \& Purwanto, 2020)bilitasi dan Rekontruksi (Pascabencana Erupsi Gunung Merapi Provinsi DIY dan Provinsi Jawa Tengah Tahun 2011-2013)

Riwayatiningsih, \& Purnaweni, H. (2017). Pemanfaatan Sistem Informasi Geografi dalam Pengembangan Pariwisata. 
Proceeding Biology Education Conference, Vol 14, No 1 (pp. 154-161). Semarang: Universitas Diponegoro.

Saputra, R., \& Purwanto, T. H. (2020). 3d Network Analysis Untuk Pemodelan Jalur Evakuasi Gedung Pascasarjana Fakultas Kedokteran, Kesehatan Masyarakat, dan Keperawatan (Fk-Kmk. Jurnal Bumi Indonesia, Vol. 9, No 1.

Wimbardana, R., \& Sagala, S. A. (2013). Kesiapsiagaan Masyarakat Terhadap Bahaya
Lahar Dingin Gunung Merapi. Jurnal Bumi Lestari, Vol. 13 No 2, 394-406.

Yusuf, Y. (2009). Analisis Risiko Bencana Kampung Mbah Maridjan Terhadap Bahaya Awan Panas Gunung Api Merapi Berbasis 3D Analysis. Simposium Nasional Sains Geoinformasi Ke-I . Surakarta: Universitas Sebelas Maret. 